\title{
PENGARUH PERAN ORANG TUA DALAM PEMEROLEHAN BAHASA PADA ANAK USIA 4-5 TAHUN
}

\section{THE INFLUENCE OF THE ROLE OF PARENTS ON LANGUAGE ACQUISITION IN CHILDREN AGED 4-5 YEARS}

\author{
Sheva Widianti Putri \\ Pendidikan Bahasa dan Sastra Indonesia \\ UIN Syarif Hidayatullah Jakarta \\ Shevawp123@gmail.com
}

\begin{abstract}
The purpose of this study explains the influence of the role of parents on language acquisition in children aged 4-5 years. The method of qualitative analysis with a descriptive approach was used in this study, through interviews and observations by researches. The interviewes were then transcribed using the note-taking method by the researcher. The research sample consisted of two sources, namely (1) Susitoh, mother of Adrian Salafas Putra and (2) Yusmiati, mother of Dimas Mahesa. The results of this study in the first sample, the most dominant stage in Adrian's development is the imitation stage in which Adrian absorbs the words mam, dalem, sewu, ojo, dan suwun. In Adrian's case, he bas reached the stage of understanding the meaning as well as communicating using the word. In the scond analysis, the dominant stages in the development of children's language acquisition are the stage of imitation and understanding meaning. The second sample, children obtained vocabulary words such as dodok and embung from the language habits of their parents.
\end{abstract}

Keywords: analysis, the role of parents, language acquisition, psycholinguistics.

\begin{abstract}
Abstrak
Tujuan penelitian ini menjelaskan pengaruh peran orang tua terhadap pemerolehan bahasa pada anak usia 4-5 tahun. Metode analisis kualitatif dengan pendekatan deskriptif digunakan pada penelitian ini, melalui wawancara dan observasi yang dilakukan peneliti. Wawancara kepada narasumber kemudian ditranskripsikan melalui metode catat oleh peneliti. Sampel penelitian terdiri atas dua narasumber yaitu (1) Susitoh, ibu dari Adrian Salafas Putra dan (2) Yusmiati, ibu dari Dimas Mahesa. Hasil penelitian ini pada sampel pertama, tahapan yang paling dominan dalam perkembangan Adrian ialah tahap peniruan ketika Adrian menyerap kata mam, dalem, sewn, ojo, dan sumun. Pada kasus Adrian, ia sudah sampai pada tahap memahami makna juga berkomunikasi menggunakan kata tersebut. Pada analisis kedua, tahapan yang dominan dalam tumbuh kembang pemerolehan bahasa anak, ialah tahapan peniruan dan pemahaman makna. Sampel kedua, anak memperoleh kosakata bahasa seperti dodok dan embung dari kebiasaan berbahasa orang tuanya.
\end{abstract}

Kata-kata Kunci: analisis, peran orang tua, pemerolehan bahasa, psikolinguistik. 


\section{Pendahuluan}

\section{Pemerolehan Bahasa Anak}

Salah satu dasar terpenting dalam kehidupan sehari-hari setiap manusia ialah penggunaan bahasa. Seorang anak memperoleh bahasa pertama kali ialah ketika ia mendengarkan langsung dari bapak atau ibunya sewaktu anak tersebut baru datang atau baru terlahir di dunia ini. Misalnya ialah seorang bayi, ia hanya memberikan respon terhadap ujaran-ujaran dari ibunya atau lingkungan sekitarnya, yang mana sangat sering didengar oleh anak bayi tersebut. Manusia hanya bisa memproduksi ujaran ketika ia telah memahami apa saja aturan-aturan yang harus diikuti, yang mana diperolehnya sejak kecil.

Kridalaksana (dalam Chaer 2003: 32), mengatakan bahwa bahasa memiliki arti sistem lambang yang bersifat arbitrer, para anggota kelompok sosial biasanya menggunakan bahasa sebagai alat komunikasi, bekerja sama, dan mengidentifikasikan dirinya. Bahasa bisa disebut sebagai alat perantara dalam proses berinteraksi satu individu dengan individu yang lain. Bahasa juga biasa digunakan sebagai alat penyampaian gagasan dari pembaca kepada pendengar atau dari penulis kepada pembaca.

Chaer (2003: 167) mengatakan bahwa pemerolehan atau akuisisi bahasa ialah prosesnya berlangsung di dalam otak anak-anak sewaktu ia mendapatkan bahasa pertamanya atau bisa disebut bahasa ibunya. Yang membedakan antara pemerolehan bahasa dengan pembelajaran bahasa ialah, pemerolehan bahasa berhubungan dengan bahasa pertama, sedangkan pembelajaran bahasa berhubungan dengan bahasa kedua si anak.

Pemerolehan bahasa adalah sebuah proses seseorang mendapatkan kemampuan untuk menangkap, menghasilkan, dan menggunakan katakata yang dapat dipahami untuk berkomunikasi. Hal-hal tersebut juga berkaitan dengan beberapa kemampuan berbahasa yang lain, seperti fonetik, sintaksis, dan memerlukan kosakata yang luas (Sundari, 2018: 54). Sedangkan, menurut Purba (2017: 1), pemerolehan bahasa pertama atau kedua mendasari pemerolehan bahasa tersebut bagaimana dapat terjadi.

Keterampilan berbahasa pada anak diperoleh melalui pengalaman-pengalaman anak, mulai dari lingkungan keluarga, masyarakat, dan sekolah. Semakin besar kontribusi orang tua terhadap perkembangan bahasa anak semakin meningkat pula perkembangan bahasa anak yang diperoleh (Rahayu, 2020 : 27). Pemerolehan yang terjadi pada anak, melalui beberapa tahap. Anak akan mengeluarkan kata-kata tanpa ada arti atau tidak ada arti dan mulai menuju pada tahap mengeluarkan kata yang mengandung arti. Selanjutnya, si anak mulai memperoleh beberapa kata dan ia mulai dapat berbicara dengan kalimat yang lengkap dan kadang-kadang diikuti dengan intonasi yang berbeda. Ketika tahap itu terjadi, maka bisa disebut bahwa anak itu sudah bisa membedakan makna dalam ucapannya. Si anak sudah bisa membedakan makna yang diucapkan walaupun kalimatnya sama.

Mangantar Simanjuntak (1982) mengemukakan bahwa pemerolehan bahasa memiliki arti bahwa penguasaan bahasa setiap individu berbeda-beda, tidak bisa langsung dan baru bisa dikatakan aktif di dalam kalangan anak-anak usia 2 - 6 tahun. Ia menjelaskan bahwa kajian mengenai pemerolehan bahasa sangatlah penting.

Seperti yang dikatakan Mangantar Simanjuntak, dalam rentang usia 2 - 6 tahun, anak sedang aktif mendapatkan pengaruh dari lingkungan sekitarnya dalam pemerolehan bahasanya. Atas dasar pendapat tersebut, saya memilih melakukan penelitian dalam rentang usia 4-5 tahun, karena dalam usia tersebut anak sedang aktif-aktifnya memperoleh pengetahuan bahasa dari lingkungan sekitarnya, terutama lingkungan keluarga. Penelitian ini bertujuan untuk melakukan penjabaran pentingnya 
peran orang tua dalam perkembangan pemerolehan bahasa anak pada usia 4-5 tahun.

\section{Teori Pemerolehan Bahasa Anak}

\section{Teori Behaviorisme}

Pada teori behaviorisme, perilaku kebahasaan seseorang diamati langsung kemudian hubungan antara stimulus dan respons juga diamati langsung. Contohnya, seorang anak yang mengucap kata bilangkali padahal maksudnya barangkali sudah tentu anak tersebut dikritik oleh orang tuanya atau oleh orang lain yang mendengar pengucapan tersebut. Namun, ketika si anak mengucapkan barangkali dengan benar, ia tidak akan mendapat kritikan dari mana pun karena pengucapannya sudah benar.

\section{Teori Nativisme Chomsky}

Menurut Chomsky, bahasa hanya dapat dimengerti sepenuhnya oleh manusia, tidak mungkin hewan dapat mengerti atau menguasai bahasa manusia. Aliran ini juga berpendapat bahwa bahasa ialah sesuatu yang rumit sehingga tidak mungkin bisa dikuasai hanya dalam waktu yang singkat melalui 'peniruan'.

\section{Teori Kognitivisme}

Teori kognitivisme, dipelopori oleh Jean Piaget (1954). Menurutnya bahasa ialah salah satu di antara banyak kemampuan yang datang atau berasal dari kematangan kognitif.

\section{Teori Interaksionisme}

Teori interaksionisme beranggapan bahwa pemerolehan bahasa adalah hasil hubungan timbal balik antara kemampuan mental pembelajaran dengan lingkungan bahasa. Howard Gardner (1983) menggambarkan, sejak lahir seorang anak telah dibekali bermacam-macam kecerdasan.

\section{Mekanisme Pemerolehan Bahasa}

a. Imitasi, terjadi ketika seorang anak mencoba menirukan pola bahasa ataupun mencoba me- nerapkan kosakata yang diserap dari lingkungan sekitar mereka, misalnya orang tua dan pengasuh anak-anak.

b. Pengondisian, diajukan oleh B.F. Skinner (1930) bahwa pembiasaan dilakukan dengan ucapan yang didengar anak dan dihubungkan dengan objek atau peristiwa yang sedang terjadi. Kosakata awal yang dimiliki oleh seorang anak ialah kata benda.

c. Kognisi sosial, seorang anak mendapatkan pemahaman terhadap kata (semantik) karena secara kognisi ia memahami tujuan seseorang memproduksi suatu fonem melalui mekanisme atensi bersama.

\section{Peran Orang Tua}

Pemerolehan bahasa sangat menarik untuk dikaji, khususnya pemerolehan bahasa anak. Pemerolehan bahasa anak dipengaruhi oleh empat faktor, yakni (1) orang tua, (2) lingkungan, (3) teman sebaya, dan (4) kegiatan komunikasi (Sri Hastuti, 1996). Orang tua memiliki pengaruh penting dalam pemerolehan bahasa anak. Oleh karena itu, kalau orang tua menginginkan anak mereka memperoleh dan menggunakan bahasa yang baik, hendaknya para orang tua memberikan contoh dan sikap yang baik ketika sedang dan akan menggunakan bahasa di depan anak-anak mereka. Anakanak pasti akan meniru contoh kata-kata yang didengar kemudian mereka serap, baik dari orang tua maupun faktor lainnya seperti yang disebutkan tadi.

Pertumbuhan dan perkembangan anak sampai pada anak tersebut berinteraksi dengan orang lain, pertama pada lingkungan sekolah, secara khusus ialah lingkungan di rumah, yaitu interaksi dengan orang tua atau anggota keluarga yang lainnya. Pada umur 4 tahun, anak biasanya sudah bisa berinteraksi dan berkomunikasi dengan cara berbicara. Orang tua yang tidak terlalu berperan yaitu tidak memperhatikan tumbuh kembang, pasti 
akan merasa kebingungan ketika mendengar anaknya berbicara.

Pada saat balita (di bawah lima tahun) adalah waktu yang sangat signifikan. Seorang anak akan mengalami perkembangan bahasa dan kemampuan bicaranya, tetapi ada yang cepat dan ada pula yang membutuhkan waktu yang lama. Dari situlah dibutuhkan bantuan atau peran orang tua langsung agar dapat memberi stimulasi sesuai dengan keunikan masing-masing anak. Selaras dengan perkembangan kemampuan juga kematangan tubuh yang berhubungan erat dengan proses bicara, komunikasi tersebut lama kelamaan makin meningkat dan meluas.

\section{Psikolinguistik}

Pemerolehan bahasa masuk ke dalam kajian psikolinguistik. Masalah kognitif berhubungan erat dengan pengetahuan mengenai bahasa karena unsur bahasa yang dipahami kemudian diproses dalam otak manusia. Pemerolehan bahasa sekarang ini berkembang dan meluas secara cepat. Penyebabnya, macam-macam perubahan pandangan bahasa ialah sepaket dengan kebiasaan ketika penguasaannya harus lewati pembentukan kebiasaan tersebut.

Kajian psikolinguistik mencoba menjelaskan proses-proses psikologi yang muncul ketika berkomunikasi dan maka secara teoritis, tujuan khususnya ialah mencari suatu teori bahasa. Secara teoritis, psikolinguistik mencoba menguraikan proses-proses psikologi yang berlangsung jika seseorang mengucapkan kalimat-kalimat yang didengarnya ketika berkomunikasi dan bagaimana kemampuan berbahasa itu diperoleh manusia. Secara teoritis, tujuan utama psikolinguistik adalah mencari suatu teori bahasa yang secara linguistis bisa diterima dan secara psikologis dapat menerangkan hakikat bahasa dan pemerolehannya (Chaer, 2009: 5 - 6). Psikolinguistik ialah ilmu yang mempelajari hubungan antara bahasa dengan perilaku dan akal budi manusia; ilmu interdisipliner linguistik dan psikologi (Kridalaksana, 2008: 203).

Menurut Robert Lado (dalam Tarigan, 2014: 3), psikolinguistik ialah gabungan pendekatan psikologi dan linguistik dalam studi pengetahuan bahasa. Menurut Lado, psikolinguistik merupakan pendekatan. Pendekatan untuk meneliti pengetahuan bahasa, pemakaian bahasa, dan hal-hal yang lain yang masih berhubungan dengan aspekaspek ini. Jelas terlihat bahwa obyek psikolinguistik ialah pengetahuan bahasa, pemakaian bahasa, perubahan bahasa, dan hal-hal lain yang ada hubungannya dengan hal-hal ini.

\section{Kajian Literatur}

Penelitian yang dilakukan oleh Arfian Hikkmat Ramdan dari Pascasarjana Linguistik Universitasi Pendidikan Indonesia. Isi penelitiannya terkait dengan pemerolehan aspek fonologis anak berusia 3 tahun yang berinisial RA. Hasil dari penelitian ini yaitu terdapat bunyi frikatif [s] dan bunyi afrikat [c], bunyi afrikat berat [j], bunyi nasal alveopalatal [n], dan bunyi getar [r] belum dapat diucapkan sempurna. Kemudian, bunyi diftong [a-u] dan [a-i] belum muncul. (bttps:// www.academia.edu/8894228/).

Penelitian Siti Nurbaya dan Mujinem dengan judul "Pemerolehan Bahasa Anak dan Peranan Orang Tua" dari FPIPS IKIP Yogyakarta menghasilkan kesimpulan bahwa (a) setiap manusia normal sudah memiliki LAD, (b) menyadari faktor yang memengaruhi pemerolehan bahasa anak. Orang tua hendaknya dapat menciptakan kondisi yang positif dalam keluarga, karena si anak akan senantiasa meniru apa saja yang diucapkan oleh orang dewasa, (c) untuk lebih memudahkan anak memahami makna kata, sebaiknya orang tua dapat melakukan koreksi sederhana terhadap kesalahan yang dilakukan si anak. 
Penelitian Prima Gusti Yanti dengan judul "Pemerolehan Bahasa Anak: Kajian Aspek Fonologi pada Anak Usia 2-2,5 Tahun” dari FKIP Universitas Muhammadiyah Prof. Dr. Hamka, Jakarta menghasilkan munculnya berbagai variasi dalam pemerolehan fonologi seorang anak sebagai narasumber, ditemukan sebagian besar disebabkan oleh belum sempurnanya alat ucap.

\section{Metode Penelitian}

Metode analisis data dalam penelitian ini adalah metode analisis kualitatif. Data yang disajikan ialah hasil wawancara, pengamatan, dan literatur. Penelitian ini merupakan jenis penelitian kualitatif dengan pendekatan deskriptif. Analisis deskriptif adalah analisis yang merinci dan menjelaskan secara panjang lebar antara keterkaitan dan penelitian dalam bentuk sebuah kalimat (Nurastuti, 2007: 203).

Informan penelitian ini adalah dua orang anak yang selain tempat tinggalnya dekat dengan peneliti ini. Selain itu juga, peneliti ini pernah sesekali saya berkomunikasi dengan kedua anak ini di mana kedua anak ini menggunakan kosakata bahasa Jawa seperti ibunya. Sesuai dengan judul penelitian, "Pengaruh Peran Orang Tua dalam Pemerolehan Bahasa", maka peneliti ini memilih narasumber dari orang tua mereka. Narasumber pertama ialah ibu Susitoh, ibu dari Adrian Salafas Putra yang kini berusia 4 tahun 5 bulan kira-kira. Narasumber kedua ialah ibu Yusniati, ibu dari Dimas Mahesa yang kini berusia 5 tahun 3 bulan.

Metode penelitian menggunakan metode wawancara dan metode catat. Di mana peneliti mewawancarai narasumber dan kemudian data ditranskrip melalui metode catat. Kelebihan penelitian dengan penggunaan metode analisis kualitatif deskriptif ialah hasil analisis yang mendalam dan peneliti memainkan peran penting sebagai alat penelitian.

\section{Hasil Penelitian}

Proses pemerolehan bahasa anak berlangsung tiga tahapan, yakni:

(1) tahap peniruan,

(2) tahap memahami makna, dan

(3) tahap menggunakan kata dalam komunikasi (Sri Hastuti, 1996).

Pada tahap pertama, orang tua harus menyadari bahwa segala sesuatu yang didengar kepada anak akan senantiasa ditiru, baik kata-kata yang bermakna jelek maupun yang bermakna baik. Kent dan Mioto (dalam Dardjowidjono, 2012: 268) mengemukakan bahwa melalui saluran intrauterine, seorang anak telah terkena bahasa ketika dia masih janin. Ketika ibunya mengeluarkan berbagai macam kata, itu akan terdengar secara biologis kemudian kata-kata itu akan melekat dan tertanam pada janin sebelum ia dilahirkan. Maka dari itu, muncullah anggapan dan kepercayaan bahwa anak biasanya lebih dekat dengan ibunya dibandingkan dengan ayahnya. Perkembangan bahasa anak itu sejalan dengan perkembangan pikiran, perasaan, dan sosial. Maka dari itu, bahasa yang keluar dari seorang anak juga telah memiliki fungsi - fungsi yang terbatas dikarenakan oleh perkembangannya yang sangat bergantung kepada kemampuan kognitif, kemampuan usia, dan kondisi lingkungan.

\section{Analisis Pertama}

Penelitian ini menggunakan data seorang anak bernama Adrian atau biasa dipanggil Iyan yang sekarang berusia 4 tahun 5 bulan. Terkait penelitian ini, peneliti ini meminta izin langsung kepada kedua orang tua Adrian, yang kemudian mereka bersedia untuk diwawancarai sebagai sumber data penelitian. Mengapa saya memilih Adrian sebagai objek penelitian dan kedua orang tuanya sebagai narasumber? Pertama, alasan saya ialah tempat tinggal mereka yang dekat dengan rumah saya, 
hanya berjarak 3 rumah saja. Kedua, saya melihat kedua orang tua Iyan terjun langsung dalam perkembangan anaknya. Memang Iyan adalah anak pertama mereka. Jadi, tak heran bila mereka sangat memperhatikan Iyan. Ketiga, saya melihat adanya pengaruh bahasa Jawa yang dibawa oleh kedua orang tuanya kepada bahasa yang diperoleh oleh Iyan. Berikut hasil transkrip wawancara saya dengan ibu Susi yang mana ialah ibu dari Iyan:

Saya : "Tante, mau tanya-tanya tentang Iyan." Ibu Iyan : "Oh... iya, silahkan."

Saya : "Tante, Iyan 'kan sekarang usianya beranjak 4 tahun, ya?"

Ibu Iyan : "Empat tahun 5 bulan, ha...ha."

Saya : "Ah, iya, he...he. Menurut Tante sebagai orang tua Iyan, apakah ada pengaruh dari Tante atau Om yang berpengaruh banget ke perkembangannya Iyan?"

Ibu Iyan : "Kalau itu mah pasti ya, secara 'kan kami berdua yang paling deket sama Iyan. Mungkin karena kami berdua berasal dari Jawa dan terlalu sering menggunakan bahasa Jawa dalam sehari-hari. Jadi, Iyan ikut - ikutan sampai sekarang dia kalau ngomong, ha...ha...ha."

Saya : "Iya, waktu itu aku beli roti buat Iyan, terus Iyan berterima kasihnya pakai bahasa Jawa, sumun, katanya. Lucu, ha...ha..."

Ibu Iyan : "Iya, itu salah satunya. Terus sekarang, memang lagi bawel ya seusia Iyan. Banyak sekali Iyan ngomongnya."

Saya : "Apa aja sih, Tante, yang pengaruh dari Tante atau Om yang turun ke Iyan, gitu?’"

Ibu Iyan : "Banyak. Mungkin yang sering dia ucap, ya?"

Saya : "Iya, boleh Tante."

Ibu Iyan: "Iya, sekarang Iyan kalau mau makan dia bilangnya mam. Jadi, kalau minta makan, bilangnya mah mo mam."
Saya : "Oh..."

Ibu Iyan : "Iya, terus juga kalau saya panggil namanya, atau bapaknya yang panggil namanya, atau kadang dipanggil orang lain, nanti dia jawabnya dalem. Itu bahasa Jawa ha...ha."

Saya : "Hm..."

Ibu Iyan : "Terus lagi, dia sekarang lagi sering bicara ojo, kalau bahasa Indonesianya jangan artinya."

Saya : "Oh, ha...ha. Lucu, ya, jadinya?"

Ibu Iyan : "Iya, memang saya dan ayahnya yang terlalu sering pakai bahasa Jawa jadi Iyan ikut-ikutan sampai sekarang."

Saya : "Iya, berpengaruh sekali ya berarti."

Ibu Iyan : "Oh, ada lagi, kemarin waktu Iyan mau beli bakso cuanki depan rumah, itu ramai, banyak anak-anak juga. Tiba-tiba dia ke saya terus minta uang sambil bilang sewu, mah. Saya kaget, ya, ha... ha... ha."

Saya : "Seribu maksudnya, Tante?"

Ibu Iyan: "Iya, minta seribu dia buat beli bakso, ha... ha... ha."

Saya : "Ha...ha. Jadi, Iyan sudah menyerap bahasa-bahasa Jawa karena Tante dan Om di rumah terus terlalu sering dalam kegiatan sehari-hari juga pakai bahasa Jawa, ya, Tante?"

Ibu Iyan : "Iya, berpengaruh. Makanya orang tua, apa yang ia bicarakan bisa anaknya meniru langsung."

Saya : "Ha...ha. Iya, Tante, terima kasih sudah menjadi narasumber tugas aku, he... he..."

Ibu Iyan : "Iya, sama-sama."

Berdasar transkrip data di atas dapat dianalisis menjadi seperti berikut: 


\section{Penggunaan kata mam}

Kata mam sendiri berarti makan dalam bahasa Indonesia. Menurut penuturan dari ibu Iyan, dirinya sering menggunakan kata mam kepada Iyan sejak Iyan masih kecil. Kebiasaan ibu Iyan menggunakan kata mam untuk menunjukkan makan terbawa sampai Iyan berumur 3 tahun sekarang ini. Penggunaan kata mam akhirnya dipakai Iyan setiap kali ia menunjukkan rasa laparnya atau ketika Iyan meminta disuapi makan.

\section{Penggunaan kata dalem}

Kata dalem ini berasal dari bahasa Jawa, yang berarti saya atau bisa juga iya. Kata biasanya dipakai oleh Iyan ketika dipanggil oleh ayah atau ibunya. Kebiasaan ini ada karena terapan dari apa yang biasanya diucapkan oleh kedua orang tuanya. Ayah dan ibu Iyan menerapkan kata dalem kepada Iyan sejak Iyan baru bisa berbicara sepatah dua patah kata. Maka, yang terekam untuk merespon panggilan dari orang lain ialah menggunakan kata dalem menurut pola pikir Iyan.

\section{Penggunaan kata sewu}

Iyan memang tumbuh dan menyerap kata-kata kebanyakan dari bahasa Jawa. Seperti kata sewu ini dalam bahasa Indonesia berarti seribu. Latar belakang kedua orang tuanya yang berasal dari Jawa sangat berpengaruh pada tumbuh kembang Iyan. Iyan selalu mengatakan kata ini ketika ia hendak membeli jajanan, kemudian ia meminta uang pada ayah atau ibunya, ketika ditanyai berapa, maka Iyan akan mengatakan sewu.

\section{Penggunaan kata ojo}

Kata ini berasal dari bahasa Jawa yang jika diartikan dalam bahasa Indonesia, yaitu jangan. Lagi-lagi pengaruh asal kedua orang tua Iyan yang berasal dari Jawa dan kemudian sering melakukan percakapan menggunakan bahasa Jawa sangat berpengaruh pada serapan kata-kata yang diperoleh oleh Iyan.

\section{Penggunaan kata suwun}

Dalam bahasa Indonesia kata ini berarti terima kasib. Iyan sering menggunakan kata ini ketika ia dibelikan sesuatu oleh orang lain. Contohnya, sewaktu saya membelikannya sebuah roti di warung yang kemudian ia sambut dengan senyum lalu berbicara sunun kepada saya.

Pada analisis pertama, tahap peniruan penggunaan bahasa jawa yang sering dipakai oleh kedua orang tua Iyan memengaruhi Iyan meniru apa yang dikatakan oleh kedua orang tuanya. Akhirnya, Iyan lebih banyak memperoleh bahasa Jawa dari kedua orang tuanya dibandingkan bahasa Indonesia sendiri (tahap peniruan). Tahap selanjutnya ialah sang anak dapat memahami makna dari kata tersebut, berangkat dari menirukan ucapan kedua orang tuanya. Akhirnya, dalam konsep kata yang diperoleh Iyan ia dapat memahami bahwa arti kata mam ialah makan (tahapan memahami makna) yang kemudian ia gunakan dalam berkomunikasi dengan orang sekitarnya menggunakan konsep kata mam ini (tahapan menggunakan kata dalam komunikasi).

Tahap yang paling dominan berdasar analisis pertama ini ialah tahap peniruan. Anak dengan sangat aktif meniru apa yang terbiasa diucapkan kedua orang tuanya sehingga ia dapat memahami makna dan menggunakan kata tersebut dalam komunikasi dengan orang sekitarnya. Asal kedua orang tuanya yang dari daerah Jawa Tengah sangat mempengaruhi peran mereka dalam pemerolehan bahasa anaknya apalagi dalam usia Iyan yang sedang aktif dalam meniru lingkungan sekitarnya dalam pemerolehan kosakata bahasanya.

\section{Analisis Kedua}

Penelitian kedua ini menggunakan data dari seorang anak yang usianya lebih tua setahun dibanding anak di sampel pertama. Anak ini bernama Dimas Mahesa. Ia lahir pada 7 Oktober 2014, sekarang usianya menginjak 5 tahun 3 bulan. 
Berbeda dengan sampel pertama yang merupakan tetangga dekat rumah saya, Dimas ini ialah seorang murid di tempat ibu saya mengajar. Sama seperti analisis pertama, saya mewawancarai narasumber, yaitu ibu dari Dimas sendiri dengan menggunakan metode catat. Berikut hasil transkrip data analisis kedua bersama ibu Yusniati, ibu dari Dimas.

Saya : "Mau tanya-tanya sedikit tentang Dimas boleh, Tante? He...he."

Ibu Dimas : "Boleh, ha...ha...ha."

Saya : "Iya, he...he, kenalan dulu aku, Sheva. Ini dengan Tante Rina, betul?"

Ibu Dimas : "Iya, betul."

Saya : "Tante, sebelumnya wawancara ini salah satu tugas penelitian dari kampus aku. Jadi, suruh analisis tentang anak-anak."

Ibu Dimas : "Oh, iya, iya, ngerti."

Saya : :He... he, yaudah langsung ya, Tante?"

Ibu Dimas : "Iya, silakan."

Saya : "Tante, Dimas ini sekarang sudah 5 tahun, ya? Selama proses perkembangannya ada tidak kebiasaan bahasa Dimas yang beda dari anak lainnya?"

Ibu Dimas : "Oh... Ini, mungkin seperti sekarang dia sering berbicara pakai kata dodok.."

Saya : "Dodok?"

Ibu Dimas : "Iya, ha...ha, duduk artinya itu. Dulu saya memang sering pakai kata dodok kalau bicara ke Dimas untuk meminta dia duduk."

Saya : "Oh, ha...ha...ha, baru paham aku." Ibu Dimas : "Terus juga dia sering bilang embung." Saya : "Gamau, ya, Tante artinya?"

Ibu Dimas : "Iya, ha...ha, memang Tante sering bicara menggunakan kata itu kalau di depan Dimas, jadi dia banyak mengikuti."
Saya : "Oalah, begitu, ha...ha."

Ibu Dimas : "Iya, pengaruh dari Tante juga memang."

Saya : "Ah, kalau begitu terima kasih banyak ya, Tante, terima kasih sudah bersedia menjadi narasumber tugas aku, he... he."

Ibu Dimas : "Iya, sama-sama, Neng."

Berdasarkan transkrip data di atas kemudian dianalisis, hasilnya sebagai berikut.

1. Penggunaan kata dodok

Kata dodok digunakan Dimas karena menurutnya, kata dodok berarti sama dengan duduk. Berdasarkan wawancara bersama ibu Dimas, ia mengakui bahwa ketika berbicara dengan Dimas sewaktu berusia 3 - 4 tahun, ia sering menggunakan kata dodok untuk mengganti kata duduk entah menurut anggapan ibu Dimas, kata dodok lebih halus ketimbang kata duduk itu sendiri.

\section{Penggunaan kata embung}

Penggunaan kata embung sama penjelasannya dengan penggunaan kata dodok, baik ayah maupun ibu Dimas terbiasa memilih kosakata embung untuk menyatakan menolak atau tidak mau. Dimas hanya meniru apa yang ia dengar dan diperdengarkan padanya.

Pengaruh peran orang tua yang membiasakan dirinya menyebutkan kata, seperti dodok dan embung kepada sang anak, membuat konsep kata tersebut melekat pada anak tersebut. Dimas, contohnya, yang memperoleh kosakata dodok dan embung dari kedua orang tuanya. Konsep kata yang anak peroleh akhirnya membuat anak memahami makna kata tersebut. Misalnya, dalam kasus Dimas, sang ibu terbiasa menggunakan kata dodok kepada Dimas untuk meminta Dimas duduk. Jadi, jelas Dimas sudah memahami makna bahwa kata dodok berarti duduk dalam konsep pemerolehan kosakatanya. Tahapan yang terakhir ialah meng- 
gunakan kata dalam komunikasi. Pada kasus Dimas, ia belum sampai pada tahap ini.

Kesimpulan pada analisis kedua ialah tidak berbeda jauh dengan analisis pertama, yaitu tahapan yang dominan dalam tumbuh kembang pemerolehan bahasa anak ialah tahapan peniruan dan memahami makna. Anak memperoleh kosakata dari hasil menirukan ucapan Ibunya seharihari dalam berkomunikasi dengannya (Dimas), kemudian anak memperoleh konsep pemahaman arti dari kata ucapan ibunya ini melalui penguasaan bahasa anak tersebut.

\section{Simpulan dan Saran}

Penelitian pertama ditemukan hasil bahwa Iyan sebagai sampelpenelitian, memperoleh bahasa Jawa yang ia ucapkan dari kedua orang tuanya yang mana berasal dari Jawa. Orang tua Iyan terbiasa menggunakan bahasa Jawa dalam kegiatan sehari-hari mereka, jadi Iyan ikut menyerap bahasa Jawa itu. Misalnya dalam penggunaan kata mam, dalem, sewu, ojo, dan suwun. Penelitian kedua ditemukan hasil bahwa Dimas memperoleh kosakata bahasa seperti dodok dan embung dari kebiasaan berbahasa orang tuanya.

Teori tiga tahapan pemerolehan bahasa menurut Sri Hastuti relevan dengan analisis tahap pemerolehan bahasa anak, mulai dari tahap peniruan, tahap pemahaman makna, dan tahap penggunaan kata dalam berkomunikasi. Kedua analisis data, baik dari Adrian maupun Dimas menunjukkan bahwa tahapan paling dominan ialah tahap peniruan. Anak sangat aktif dalam menyerap apa yang diucapkan orang di lingkungan sekitarnya sehingga anak ini memiliki konsep pemahaman makna dari kosakata yang ia serap. Dapat dipahami dan dimengerti bahwa pemerolehan bahasa pertama ialah suatu proses bagaimana anak dapat memperoleh kemampuan bahasa ibunya secara alami sesuai dengan perkembangan kognitif, interaksi sosial si anak, dan perkembangan linguis- tik si anak itu sendiri. Pengaruh peran orang tua yang ditunjukkan dalam kedua kasus ini adalah dalam penggunaan bahasa saat komunikasi bersama dengan sang anak yang menjadikan anak tersebut memperoleh kosakata yang sebelumnya asing menjadi dapat dipahami maknanya. Pemerolehan bahasa anak lebih kepada bahasa pertamanya atau bahasa ibu. Itulah sebabnya mengapa anak menggunakan bahasa yang ia serap dari kedua orang tuanya untuk menunjukkan perasaan atau keinginannya.

\section{DAFTAR PUSTAKA}

Chaer, Abdul. 2003. Linguistik Umum. Jakarta: Rineka Cipta.

Chaer, Abdul. 2009. Psikolinguistik Kajian Teoritik. Jakarta: Rineka Cipta.

Dardjowidjojo, S. 2012. Psikolinguistik: Pengantar Pemahaman Bahasa Manusia. Jakarta: Yayasan Obor Indonesia.

Hastuti, Sri. 1996. Tentang Pendidikan Akuisisi Bahasa Anak Kita. Jakarta: Kedaulatan Rakyat.

Kridalaksana, Harimurti. 2008. Kamus Linguistik. Jakarta: PT Gramedia Pustaka Utama.

Nurastuti, Wiji. 2007. Metodologi Penelitian. Yogyakarta: Ardana Media.

Purba, Andiopenta 2013. "Peranan Lingkungan Bahasa dalam Pemerolehan Bahasa Kedua". Dalam Jurnal Pena. Vol. 3. No. 1. Juli.

Rahayu, Della Mustika. 2020. "Pengaruh Peran Orang Tua terhadap Perkembangan Bahasa dan Bicara Anak Usia Dini”. Dalam Jurnal Pedagogi. Vol. 20, No. 1. April.

Sundari, Weli. 2018. "Pemerolehan Bahasa". Dalam Jurnal Warna. Vol. 2. No. 1. Juni.

Tarigan, Henry Guntur. 2014. Menyimak sebagai Suatu Keterampilan Berbahasa. Bandung: Angkasa. 